\title{
Roche vows to keep Genentech culture
}

An era has ended for the biotechnology industry with the full merger of biotech pioneer Genentech, of South San Francisco, and Swiss pharmaceutical giant Roche, based in Basel.

The deal, announced on 12 March, ends Roche's eight-month pursuit of Genentech. Roche's final offer of about $\$ 46.8$ billion $-\$ 95$ a share - will buy it the $44 \%$ or so of Genentech that it doesn't already own. The merger is the latest of several mega-mergers rippling through the drug industry (see 'Getting it together').

But the Roche-Genentech deal has a unique resonance in the science and biotech communities, because Genentech's creative culture and rigorous science have been seen as essential to its ongoing success in producing novel medicines. And although Roche has vowed to preserve Genentech's entrepreneurial scientific culture, observers say that this may not be possible under Swiss leadership.

"It just seems unlikely that Genentech can maintain its creativity, because the difference between the two corporate cultures is not a superficial one," says Laurence Lasky, who worked at Genentech from 1982 to 2002 and was a Genentech fellow - the company's top science rank - when he left. "It's sad, because Genentech really is one of the greatest homegrown things that we have created in this country," says Lasky, who is now a partner at US Venture Partners of Menlo Park, California.

In a statement on the deal, the two companies said that Genentech's "unique culture [will be] maintained". Company executives are not speaking to the press about how exactly this will be accomplished. But former Genentech employees say that similar fears surfaced in 1990, when Roche bought a majority stake in Genentech, and proved to be unfounded. "That partnership didn't hurt our creativity; Roche stayed at a distance and Genentech continued to do great work," says David Goeddel, who was the first scientist hired at Genentech and is now a managing partner at the venture-capital firm the Column Group in San Francisco.

But, Goeddel adds, "I think the complete loss of any independence for Genentech is kind of sad after so many years".

Founded in 1976, Genentech grew from a tiny start-up to an almost $\$ 100$-billion company by capitalizing on pioneering science. For instance, Genentech scientists were the first to engineer bacteria to produce human proteins, such as insulin, which became the company's first drug — and the world's first genetically engineered drug — in 1982.

Since then, Genentech has developed a

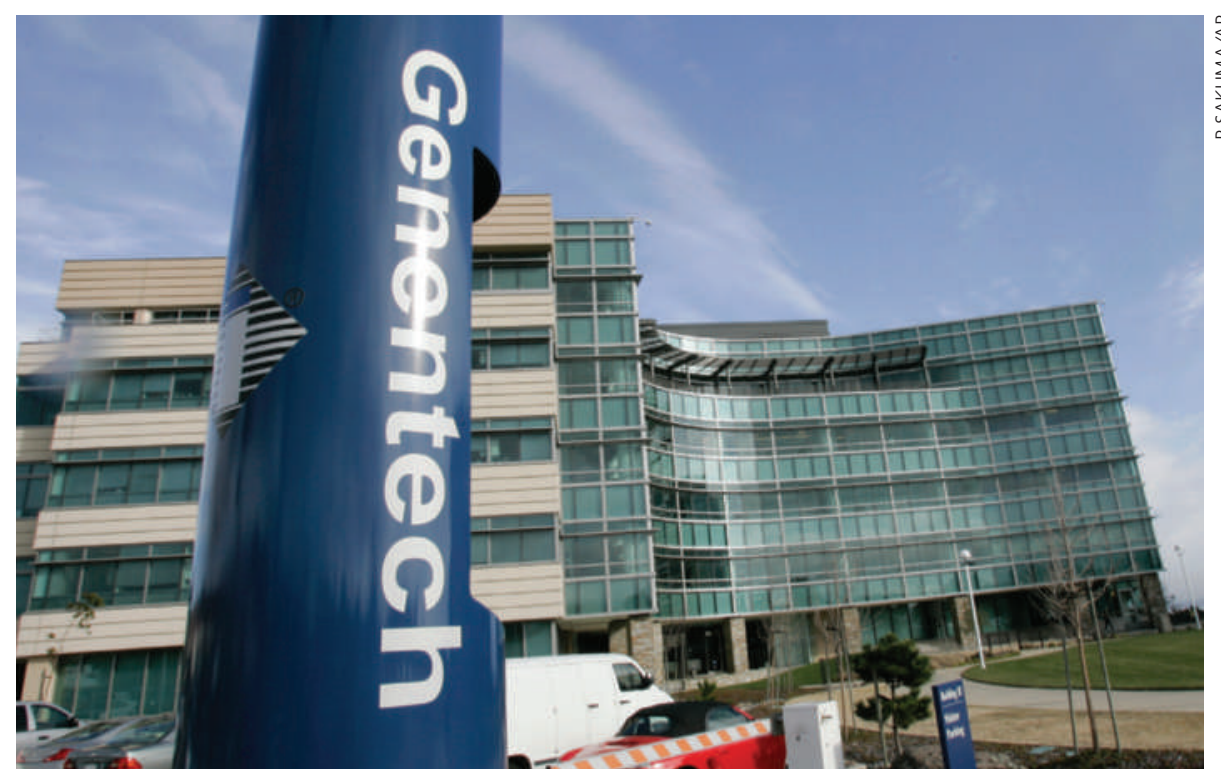

Genentech's reputation for scientific creativity is often credited with its success in drug development.

pipeline of biological drugs worth $\$ 9.5$ billion in annual sales in the United States alone. Three of these are now Roche's best sellers. One, the cancer medicine bevacizumab, sold as Avastin, is already worth $\$ 4.8$ billion a year and is currently in clinical tests, due to report results in about a month, that may expand its uses.

Genentech's story has served as a model for the rest of the biotech industry, and young companies often speak of aspiring to become the next Genentech. But, Goeddel says, "that's pretty impossible to do now". Panicked by their own lack of promising drug candidates, big pharmaceutical companies are picking off small biotechs at a much earlier stage than they did in the

\section{Getting it together}

2009 is shaping up to be the year of the pharmaceutical mega-merger. Analysts say that such mergers are likely to be only a short-term fix for companies' dwindling drug pipelines. Among the recent highlights: January 2009: Pfizer acquires Wyeth for $\$ 68$ billion, in part to make up for the fact that its blockbuster cholesterol drug Lipitor comes off patent in 2011.

March 2009: Merck buys ScheringPlough for $\$ 41$ billion, in part to acquire the company's pipeline of drugs in the late stages of development.

March 2009: Roche, which already owned a majority stake in Genentech, buys out the rest of the company for $\$ 47$ billion. past, preventing the companies from evolving independently. Some of the other early biotech companies have survived as a result of mergers and acquisitions: Biogen, based in Cambridge, Massachusetts, merged with Idec of San Diego, California, in 2003, and Amgen, headquartered in Thousand Oaks, California, has acquired several smaller biotechs over the years.

Roche is thought to have been spurred to solidify its hold over Genentech because its exclusive rights to sell Genentech products outside the United States were set to expire in 2015. Roche first bid for Genentech last July, offering $\$ 44$ billion, or $\$ 89$ per share, for the rest of the company.

Now that the two firms have agreed on a final number, the merged company is set to become the seventh largest pharmaceutical firm in the United States, with an annual revenue of about $\$ 17$ billion. It will retain the Genentech brand in the United States and will be headquartered at Genentech's South San Francisco campus.

But the campus may see an exodus of Genentech employees, possibly including chairman and chief executive Arthur Levinson, who joined the company in 1980. "My guess is it would be very hard for [Levinson] to stay, because he's used to running his own show," Lasky says. Levinson is not speaking to reporters, but said in a statement: "We look forward to working with our partners at Roche to ensure a smooth transition once the transaction is complete and to continue our mission of serving patients." Erika Check Hayden 